\title{
ANALISIS KINERJA DINAS PASAR DALAM MENINGKATKAN EFISIENSI DAN EFEKTIVITAS PENGELOLAAN SISTEM AKUNTANSI RETRIBUSI PASAR (Studi Empiris pada Dinas Pasar Kota Semarang)
}

\author{
Oleh : \\ Intan Faria Rohyati \\ Hardi Winoto \\ Program Studi Akuntansi \\ Fakultas Ekonomi \\ Universitas Muhammadiyah Semarang
}

\begin{abstract}
:
The purposeof this study is to analyze the level of efficiency and effectiveness of market acceptance of retribution, to analyze the performance of the market acceptance, along with analyzing the suitability of recording and reporting on financial SKPD in the city of Semarang, Particulary Semarang Office Market with Permendagri No. 13 of 2006 and Government Regulation No. 24 of 2005.

In conducting this study, the writer uses a descriptive qualitative and quantitative research design. Interview and documentation techniques to collect data. The results of the study showed that the market levy acceptance of the 20082012 is very effective in the amount of $100.63 \%$ and the cost is said to be efficient levied at $7.3 \%$. And the Department of Semarang City Market has made the process of accounting records in accordance with the Regulation of the Minister of Home Affairs No. 13 of 2006 and Government Regulation No. 24 of 2005, whereas for the preparation of financial statements in accordance with the Regulation of the Minister of Home Affairs No. 13 of 2006, financial statements were prepared on time so that it can be used for user groups to Financial Statements decision.
\end{abstract}

Keywords: Revenue Performance, Recording and Reporting Process Office Market Semarang. 


\section{PENDAHULUAN}

Salah satu cara untuk meningkatkan PAD adalah dengan meningkatkan pendapatan dari retribusi yang dalam hal ini adalah samua retribusi yang dapat dipungut dari pasar, yaitu retribusi pasar. Dengan adanya Undang-Undang Nomor 32 tahun 2004 tentang Pemerintah Daerah, maka pasar tidak hanya sebagai unit pelayanan kepada masyarakat, tetapi pasar sudah merupakan unit usaha bagi Pemerintah Daerah sehingga diharapkan dapat menghasilkan laba retribusi. Apabila hal itu dapat terpenuhi, maka sumber pendapatan dapat digunakan oleh Pemerintahan kota Semarang untuk meningkatkan pelayanan kepada masyarakat dan pada akhirnya dapat untuk meningkatkan kemakmuran masyarakat kota Semarang.

Satuan Kerja Perangkat Daerah (SKPD) merupakan bagian dari pemerintahdaerah yang melaksanakan fungsi pemerintahan dan pelayanan publik, baik secaralangsung ataupun tidak. Untuk melaksanakan tugas pokok dan fungsinya tersebut,SKPD diberikan alokasi dana (anggaran). Oleh karena itu, kepala SKPD disebutjuga Pengguna Anggaran (PA).Selaku Pemegang Kekuasaan Pengelolaan Keuangan Daerah (PKPKD),Kepala Daerah (Gubernur, Bupati, Walikota) yang mendelegasikan sebagiankewenangannya kepada kepala SKPD, pada akhirnya akan meminta kepala SKPDmembuat pertanggungjawaban atas kewenangan yang dilaksanakannya. Bentukpertanggungjawaban tersebut bukanlah SPJ (surat pertanggungjawaban), tetapiberupa laporan keuangan. Penyebutan SKPD selaku entitas akuntansi (accountingentity) pada dasarnya untuk menunjukkan bahwa SKPD melaksanakan prosesakuntansi untuk menyusun laporan keuangan yang akan disampaikan kepadaGubernur/Bupati/Walikota melalui Pejabat Pengelola Keuangan Daerah sebagaibentuk pertanggungjawaban pengelolaan keuangan daerah.

Kertas kerja / Laporan keuangan oleh SKPD ini dilatarbelakangi olehPeraturan Menteri Dalam Negeri No. 13 Tahun $2006 \quad$ Tentang PedomanPengelolaan Keuangan Daerah dan Peraturan Pemerintah Nomor 24 tahun 2005tentang Standar Akuntansi Pemerintahan. DinasPasarsebagai salah satu Satuan Kerja Perangkat Daerah (SKPD) yang ada di wilayahPemerintah Semarang sekaligus sebagai penggunaanggaran juga harus membuat pertanggungjawaban atas kewenangan yangdilaksanakannya sesuai dengan Peraturan Menteri Dalam Negeri Nomor 13 Tahun2006 Tentang Pedoman Pengelolaan Keuangan Daerah dan Peraturan PemerintahNomor 24 tahun 2005 tentang Standar Akuntansi Pemerintahan. Dan berdasarkanPeraturan Menteri Dalam Negeri No 13 tahun 2006 tentang Pedoman PengelolaanKeuangan Daerah pasal 232 ayat (5) disebutkan bahwa dalam rangkapertanggungjawaban pelaksanaan APBD sebagaimana dimaksud pada ayat (3),entitas pelaporan menyususn laporan keuangan yang meliputi Laporan RealisasiAnggaran, Neraca, Laporan Arus Kas, dan Catatan Atas Laporan Keuangan.

\section{TUJUAN PENELITIAN}

Penelitianinibertujuan untuk mengetahui apakah Dinas Pasar Kota Semarang telah melakukan pencatatan akuntansi dengan baik (dengan Peraturan Menteri Dalam Negeri No.13 tahun 2006 tentang Pedoman Pengelolaan Keuangan Daerah dan Peraturan Pemerintah Nomor 24 Tahun 2005 tentang Standar Akuntansi Pemerintahan ) sebagai acuan. Dan mengetahui apakah Dinas Pasar Kota Semarang telah menyusun Laporan Keuangan dengan baik (dengan Peraturan Menteri Dalam Negeri No.13 tahun 2006 tentang Pedoman Pengelolaan Keuangan Daerah dan Peraturan Pemerintah Nomor 24 Tahun 2005 tentang Standar Akuntansi Pemerintahan ) sebagai acuan. 
Serta Untuk mengetahui dan menganalisis seberapa besar tingkat efesiensi dan efektivitas penarikan retribusi pasar di kota Semarang.

\section{TINJAUAN PUSTAKA}

Menurut Sunarto (2005) retribusi pasar adalah pungutan yang dikenakan pada pedagang oleh Pemerintah Daerah sebagai pembayaran atas pemakaian tempat-tempat berupa toko / kios, counter / los, dasaran, dan halaman pasar yang disediakan didalam pasar daerah atau pedagang lain yang berada di sekitar pasar daerah lainnya yang berada di sekitar pasar daerah sampai dengan radius 200 meter dari pasar tersebut.

Berdasarkan Undang-Undang nomor 18 Tahun 1997 tentang pajak dan retribusi daerah yang mengalami perubahan dengan diberlakukan UndangUndangNomor 34 tahun 2000, dan Peraturan Pemerintah Nomor 66 Tahun 2001 tentang retribusi daerah, disebutkan bahwa retribusi pasar masuk ke dalam kelompok retribusi jasa umum. Retribusi jasa umum tersebut tidak bersifat komersial. Dengan demikian retribusi jasa umum merupakan pelayanan yang disediakan atau diberikan Pemerintah Daerah untuk tujuan kepentingan umum.

Untuk mengetahui efisiensi dalam penerimaan retribusi pasar dapat dilihat dengan menggunakan analisis efisiensi pemungutan retribusi pasar. Analisis ini dihitung dengan cara membandingkan antara jumlah biaya yang dikeluarkan untuk pemungutan retribusi pasar tersebut dengan realisasi penerimaan retribusi pasar yang biasanya dinyatakan dalam persentase ( Mardiasmo, 2002). Formula yang digunakan untuk menghitung efisiensi pemungutan retribusi pasar dengan Cost of Collection Efficiency Ratio( CCER).

\section{CCER=}

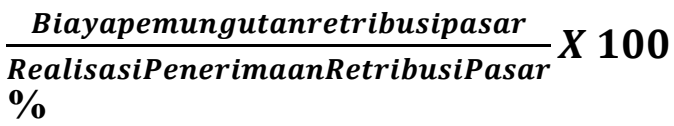

Tabel 2.1

Kriteria Penilaian Kinerja Efisiensi

\begin{tabular}{|c|c|}
\hline $\begin{array}{c}\text { Persentase } \\
\text { Kinerja } \\
\text { Keuangan } \\
\text { ( Persen ) }\end{array}$ & Kriteria \\
\hline $100-$ Ke atas & Tidak Efisien \\
\hline $90-100$ & Kurang Efisien \\
\hline $80-90$ & Cukup Efisien \\
\hline $60-80$ & Efisien \\
\hline Di bawah 60 & Sangat Efisien \\
\hline
\end{tabular}

Sumber : KeputusanMenteri Dalam Negeri No. 690.900.327 Th.1996

Menurut Devas CN (1989) efektivitas menggambarkan hubungan antara realisasi penerimaan retribusi pasar terhadap target penerimaan retribusi pasar yang memungkinkan apakah besarnya retribusi pasar sesuai dengan target yang ada. Apabila hasil perhitungan efektivitas retribusi pasar menghasilkan angka / presentase mendekati 100 persen, maka dikatakan efektif. Menurut Devas CN (1989) efektivitas dapat dihitung dengan rumus sebagai berikut :

\section{rasio ef ektivitas}

$$
=\frac{\text { realisasi penerimaan retribusi pasar }}{\text { target penerimaan Retribusi pasar }} \times 100 \%
$$

Menurut keputusan Menteri Dalam

Negeri Nomor 690.900.327 Tahun 1996 tentang Pedoman Penilaian dan Kinerja Keuangan, maka kriteria efektivitas kinerja keuangan dapat dilihat pada Tabel 2.2 sebagai berikut :

\section{Tabel 2.2}

Kriteria Efektivitas Kinerja Keuangan

\begin{tabular}{|c|c|}
\hline $\begin{array}{c}\text { Persentase Kinerja } \\
\text { Keuangan } \\
\text { ( Persen })\end{array}$ & Kriteria \\
\hline Di atas 100 & Sangat Efektif \\
\hline $90-100$ & Efektif \\
\hline $80-90$ & Cukup Efektif \\
\hline $60-80$ & Kurang Efektif \\
\hline Di bawah 60 & Tidak Efektif \\
\hline
\end{tabular}




\section{METODE PENELITIAN}

Data yang digunakan dalam penelitian ini adalahData kuantitatif adalah data dalam bentuk angka-angka dan dapat dinyatakan dalam satuan hitung. Dan Data kualitatif adalah data yang dinyatakan dalam bentuk kata, kalimat dan gambar.

\section{Metode Pengumpulan Data}

a. Observasi

Observasi adalah teknik pengumpulan data dengan cara mengadakan pengamatan langsung terhadap obyek yang diteliti dan melakukan pencatatan secara cermat dan sistematis terhadap catatan dan dokumen seperti laporan realisasi penerimaan dan penyetoran retribusi pasar kota semarang, biaya pemungutan retribusi.

b. Wawancara

Wawancara adalah teknik pengumpulan data dengan cara mengadakan tanya jawab langsung dengan pihak-pihak yang terkait untuk memperoleh keterangan sesuai dengan permasalahan yang diteliti, yaitu informasi mengenai gambaran umum dinas pasar dan sistem akuntansi dinas pasar.

\section{Sumber Data}

Data primer adalah data yang diperoleh atau dikumpulkan oleh peneliti secara langsung dari sumber datanya. Data primer disebut juga sebagai data asli atau data baru yang memiliki sifat up to date. Untuk mendapatkan data primer, peneliti harus mengumpulkannya secara langsung.

Data Sekunder adalah data yang diperoleh atau dikumpulkan peneliti dari berbagai sumber yang telah ada (peneliti sebagai tangan kedua). Data sekunder dapat diperoleh dari berbagai sumber seperti Biro Pusat Statistik (BPS), Dinas Pasar Kota Semarang.

\section{Teknik Analisis Data}

Teknik analisis data yang digunakan dalam penelitian ini menggunakan teknik analisis deskriptif kuantitatif. Metode ini menerapkan konsep perhitungan rasio keuangan, yaitu dengan menghitung rasio keuangan dari pos-pos dalam Realisasi Anggaran yang tertuang dalam Laporan Realisasi Anggaran untuk tahun anggaran 2012. Metode ini dilakukan dengan memperhatikan indikator kinerja Dinas Pasar dalam mengelola keuangannya dengan menggunakan rasio-rasio.

\section{HASIL PENELITIAN}

Hasil perhitungan efisiensi
pemungutan retribusi pasar Kota Semarang menunjukkan bahwa selama periode 2008-2012 efisiensi pemungutan retribusi pasar berturut-turut sebesar 8,98 persen, 7,47 persen, 7,12 persen, 6,58 persen, 6,33 persen. Ratarata efisiensi setiap tahunnya sebesar 7,3 persen. Dari angka tersebut dapat diketahui bahwa pemungutan retribusi pasar di Kota Semarang sangat efisien, karena nilai CCER retribusi pasar lebih kecil dari $100 \%$. Jika nilai CCER semakin kecil dari nilai $100 \%$, maka menunjukkan bahwa hasil penerimaan retribusi pasar semakin besar daripada biaya yang dikeluarkan. Sehingga kinerja Kinerja Dinas Pasar Kota Semarang Dikatakan sangat efisien. Bila angka CCER diatas 100\% maka dapat dikatakan bahwa kinerja pemungutan retribusi pasar tidak efisen. Karena biaya pemungutan yang dikeluarkan lebih besar daripada penerimaan yang dihasilkan.

Efektivitasmenunjukkan bahwa penerimaan retribusi pasar dari tahun 2008-2012, telah berjalan sangat efektif. Hal ini ditunjukkan dengan nilai efektivitas yang lebih besar dari nilai 100 persen. Pada tahun 2008, nilai efektivitas yaitu sebesar 100,53 persen. Kemudian pada tahun 2009 nilai efektivitas kembali meningkat yaitu, 100,66 persen. Tahun 2010 dan 2011 efektivitas mengalami penurunan yaitu sebesar 100,59 dan 99,89 persen. Sedangkan pada tahun 2012 mengalami peningkatan sebesar 101,51 persen. Perkembangan nilai efektivitas penerimaan retribusi pasar pun semakin meningkat. Berarti menunjukkan nilai efektivitas yang semakin baik. Bila 
nilai efektivitas semakin besar maka penerimaan retribusi pasar semakin besar. Realisasi penerimaan retribusi pasar dari tahun 2008-2012 semakin besar pula.

\section{KESIMPULAN}

Berdasarkan hasil penelitian diketahui bahwa efisiensi biaya pemungutan retribusi pasar selama periode 2008-2012 sebesar 8,98 persen, 7,47 persen, 7,12 persen, dan 6,58 persen. Rata- rata efisiensi biaya pemungutan retribusi pasar dari tahun 2008-2012 adalah sebesar 7,29 persen. Dari angka tersebut dapat dikatakan efisien, karena setiap Rp 1 biaya pemungutan retribusi pasar yang dikeluarkan Dinas Pasar Kota Semarang untuk menghasilkan realisasi penerimaan retribusi pasar sebesar 7,29 persen. Maka dapat dikatakan kinerja Dinas Pasar Kota Semarang Berjalan dengan baik.

Berdasarkan hasil penelitian diketahui bahwa efektivitas penerimaan retribusi pasar dari tahun 2008-2012 sebesar 100,53 persen, 100,66 persen, 100,59 persen, 99,89 persen dan 101,51 persen. Rata-rata efektivitas dari tahun 2008-2012 sebesar 100,636 persen. Hal ini menunjukkan bahwa penerimaan retribusi pasar dari tahun 2008-2012 telah efektif. Maka dapat dikatakan kinerja Dinas Pasar Kota Semarang berjalan dengan baik.

\section{DAFTAR PUSTAKA}

Bastian, Indra. 2001. Akuntansi Sektor Publik.Andi. Yogyakarta.

$$
\text { 2007. Akuntansi Sektor }
$$

Publik. Salemba Empat. Jakarta.

Devas, Nick. 1989. Keuangan Pemerintah Daerah di Indonesia. UI Press. Jakarta.

Halim, Abdul. 2002. Akuntansi Sektor Publik: Akuntansi Keuangan Daerah.Edisi Ketiga. Salemba Empat. Jakarta.

2007. Manajemen

Keuangan Bisnis. Ghalia Indonesia. Bogor.

Harianja, Riodinar, 2008. Penerapan Sistem Akuntansi Pemerintahan pada
Satuan Kerja Pengelola Keuangan Daerah

(SKPKD)

PemerintahKabupaten Toba Samosir, Skripsi Fakultas Ekonomi Universitas Sumatera Utara, Medan.

Kaho, Josef Riwu. 1998. Prospek Otonomi Daerah di Negara Republik Indonesia. Rajawali Pers. Jakarta.

Kurniawan, Panca dan Agus Purwanto. 2006. Pajak Daerah dan Retribusi Daerah di

Indonesia. Cetakan ke-2. Bayumedia Publishing. Malang.

Mardiasmo. 1997. Otonomi dan Manajemen Keuangan Daerah. Penerbit Andi.Yogyakarta.

Mardiasmo.2002.Perpajakan. Edisi Revisi.Andi.Yogyakarta.

Mulyadi. 2001. Sistem Akuntansi. Edisi Ketiga. STIE YKPN. Yogyakarta.

Mulyanto, Agus. 2009. Sistem Informasi Konsep dan Aplikasi. Pustaka Pelajar. Yogyakarta.

Pangesti, Karunia Sari Nur. 2008.Implementasi Sistem Akuntansi SKPD : Studi Kasus Penerapan Permendagri Nomor 13 Tahun 2006 di Pemerintah Daerah Kabupaten Batang, Tesis Fakultas Ekonomi UniversitasGajah Mada, Yogyakarta.

Purnamasari, Gesit. 2006.Analisis Penerimaan Retribusi Pasar dalam Upaya Meningkatkan PAD di Kabupaten Temanggung, Skripsi Sarjana, Fakultas Ekonomi, Universitas Diponegoro, Semarang.

Republik Indonesia. 1997. Undang Undang Nomor 18 Tahun 1997 sebagaimana telah diubahdengan Undang Undang Nomor 34 Tahun 2000 Tentang Pajak Daerah dan Retribusi Daerah.

Santoso, Bagus.1995.Retribusi Pasar Sebagai Pendapatan Asli Daerah Studi Kasus Di Kabupaten Sleman. Jakarta.

S, Munawir. 2004. Analisis Laporan Keuangan. Edisi Keempat. Liberty. Yogyakarta. 
Soejamto. 1987. Aspek- aspek Pengawasan di Indonesia. Sinar Grafika. Jakarta.

Soeparmoko. 2002. Ekonomi Publik untuk Keuangan dan Pemerintahan Daerah.Penerbit Andi. Yogyakarta.

Sunarto. 2005. Manajemen Sumber Daya Manusia Strategik. Amus. Yogyakarta.

Susanto, Azhar. 2008. Sistem Informasi Akuntansi. Lingga Jaya. Bandung.

Yuliningsih, Tatik. 2002.Analisis Efektivitas Pemungutan Retribusi PasarKabupaten Purbalingga, Skripsi Sarjana, Fakultas Ekonomi, Universitas Diponegoro, Semarang.

Widjaja. 1998. Otonomi Daerah dan Daerah Otonom. PT. Raja Grafindo Persada.Jakarta. 